\title{
The Diffusion of Protestantism in Northern Europe: Historical Embeddedness and Complex Contagions in the Adoption of the Reformation
}

\author{
Bernd Wurpts, Katie E. Corcoran and Steven Pfaff
}

\begin{abstract}
In this article we use network theory to explain the adoption of the Protestant Reformation. We use new historical data on the connections between Hansa towns that allow us to conduct the first social network study of the Protestant Reformation. Based on an analysis of cities in central and Western Europe between 1517 and 1530, we find evidence for diffusion through both simple and complex contagion. Our operationalization of network data based on medieval Hansa Diets points to the complex association between tie weights (i.e., the strength of ties) and numbers of ties in network diffusion. Using optimal tuning parameters for simple adoption models, we show that a combination of strong ties and weak ties fostered Protestant adoption in northern cities.
\end{abstract}

\section{Introduction}

In 2017 many towns in Europe celebrated the 500-year anniversary of the Protestant Reformation (officially, the Lutherjahr in Germany). The Reformation has often been treated as an epoch-marking event separating the late Middle Ages from the early modern period. Another separation is the geographical division of Europe by religion. Since the 1600s, a line runs through the middle of Germany, separating a Protestant North from a Catholic South. Why did Protestantism become particularly dominant in Northern Europe?

The Reformation has been a topic of interest in sociology at least since Max Weber (1978 [1904-5]). Like Weber, most social scientists have focused on the consequences of the Reformation, but a growing literature interested in major historical transitions and institutional change has begun to analyze the factors that caused it. In a review of the literature, Becker et al. (2016: 41) offer the following list as established factors related to the origins of the Protestant Reformation: "advances in information technology (the printing press); outside threats (the Ottomans) that sidetracked the attention and resources of the papacy and Habsburgs; the heterogeneous and decentralized nature of the HRE [Holy Roman Empire]; and networks of sympathetic university students and intellectuals placed in strategic locations throughout the HRE."

The aim of this study is to explain why the Protestant Reformation was particularly successful in the northern region of the HRE. The HRE was a loose electoral monarchy based on a confederation of principalities and cities. Cities had substantial autonomy in deciding whether to retain the Roman church or institute a different religious regime (Cantoni 2012; Pfaff and Corcoran 2012; Rubin 2014). Medieval German town-law (Stadtrecht) provided for self-government, the right to tax, and town councils with binding powers. The north was characterized by weak, relatively poor princes and many medium-sized commercial cities. Because of the lack of centralization, there 
was no decisive crown interest that could determine whether Protestantism or Roman Catholicism would prevail (Kohler 1990; Neuhaus 1997; Nexon 2009). The Protestant movement in this place and time provided a unique opportunity for civic elites to decide whether to retain or overthrow the local Catholic monopoly.

Why were Northern German towns among the early adopters of the new religion even though local elites initially opposed the Reformation? In explaining the coming of the Protestant Reformation, economic historians have long argued that it was driven by "an immense expansion of commerce and finance" in the decades before 1517 (Tawney 1954 [1926]: 73; see also Becker et al. 2016). Economic accounts suggest that development fostered social diversification and, with it, shifting demand for new spiritual goods that the Roman Church was slow to deliver (Ekelund et al. 1996, 2006; Pfaff and Corcoran 2012). Moreover, Protestantism was putatively appealing to merchants and burghers because it was good for business and easier on the pocketbook. It promised an end to restrictions on labor and commerce; lowered the financial cost of achieving salvation; ended tax exemptions for the clergy and religious foundations; and promised to rationalize laws and civic governance (Ekelund et al. 1996).

Previous studies claim that members of the medieval Hansa (or Hanseatic League), an association of merchants and trading cities that had extensive ties within northern Germany and abroad, were more prone to reform compared with other cities in the HRE. ${ }^{1}$ This is because trade, economic growth, and commercial development putatively made cities more likely to adopt Protestantism (Cantoni 2012; Ekelund et al. 2006; Rubin 2014; Sombart 1915; Tawney 1954 [1926]). However, detailed data on economic development and flows of trade between cities are unavailable for the sixteenth century, leading to a heavy reliance on proxy measures in multivariate analyses. Recent studies have included an indicator variable for membership in the Hanseatic League (or medieval Hansa) to capture the effects of trade (Cantoni 2012; Dittmar and Seabold 2014; Kim and Pfaff 2012; Pfaff and Corcoran 2012; Rubin 2014). Depending on model specification, most analyses find a positive (if not always statistically significant) association between Hansa membership and the institution of reform.

But why did the Hansa matter? Previous studies include a measure of league membership in lieu of some other unmeasured variable. For Dittmar and Seabold (2014), membership is a mere control variable. Cantoni (2012: 513) treats Hansa membership as indicative of "the likely preponderance of trading activity," similarly, Pfaff and Corcoran (2012: 762, 767) use it to capture "the relative importance of trade in a city's economic activity," as well as the "prominence of merchant guilds." Rubin

1. The broadest definition of the Hanseatic League (or, Hansa) is as an organization of Low-German long-distance traders and the towns in which they had citizenship (Hammel-Kiesow 2008). The Hansa was a trade confederation that relied on the subsidiary organization of the self-governing city, "not a town league nor a guild, but [which] relied on town administrations and local (as well as alien) guilds in order to function" (Wubs-Mrozewicz 2012: 10). Trade privileges were the backbone of the organization and mutual aims included the protection of trade routes; standardization of goods and prices; and procedures and practices governing in- and out-group relations. Hansa merchants traded over large distances stretching from Northern Russia to the Mediterranean Sea. 
(2014: 275) uses membership as a proxy for "better access to information flows and greater wealth."

The inconsistent significance of Hansa membership in multivariate analyses and the way in which membership serves as a proxy for a host of relationships call the meaning of the variable into question. ${ }^{2}$ Was there something specific about the league, its members, or their relations that made them more apt to reform than other towns? The inconsistent performance of the Hansa membership variable across studies is just one reason to question the association between the Hansa and the adoption of Protestantism. A second reason relates to the geographical distribution of Protestant towns in central Europe that roughly corresponds to the areas of Hansa activity. A recent study observes that "[w]hile the cities lying North-east of the Muenster-Erfurt axis are all Protestant, the cities in the south-east and Austria are mostly Catholic" (Curuk and Smulders 2016: 24). Curuk and Smulders argue that the Reformation succeeded in the north due to prevailing market inefficiencies (particularly in unmet agricultural potential) reinforced by the Catholic Church. As the inefficiencies were particularly large in the northern regions, regional rulers had greater incentives for (institutional) regime change compared to their counterparts in the south.

While Curuk and Smulders point to important environmental differences between the Protestant and Catholic regions, it is unclear whether local authorities were interested in expanding market potential or were aware of relative market inefficiencies. The emphasis on the rational incentives of "regional rulers" ignores the diversity in types of rulers and how decision making was reached in early-sixteenth-century cities. In fact, the primary locus of religious decision making, particularly early in the Reformation, was in the cities, not in the territorial principalities. Historians have shown that the main thrust of the popular movement that propelled Protestantism took place in cities in the 1520s (Blickle 1992; Brady 1998; Mörke 2005; Ozment 1975; Schilling 1988; Scribner 1986).

Our unit of analysis is a sample of large cities in central and Western Europe encompassing the HRE collected by Rubin (2014). The data including 753 cities in central and Western Europe show that about 11 percent of all cities had adopted the Reformation by 1530. The temporal prominence of the Hanseatic towns is conspicuous in that more than a fifth of all the cities that had reformed by 1530 were members of the Hansa, a sizable share because the northern regions of the HRE were less densely urbanized than the south. Moreover, while the adoption of Protestantism was highly mixed in other commercially advanced parts of the empire such as the southwest and along the Rhine, nearly all the northern towns ultimately adopted it—generally in advance of the princes in whose territories these cities were located.

Whereas a very high proportion of Hanseatic towns reformed in regions, such as along the North and Baltic seas, the adoption of Protestantism was more mixed among the Hansa towns along the Rhine and in interior areas. Moreover, the urban

2. Another problem is that the variable is coded from different sources, including Dollinger (1970), Pagel (1983), and Jacob (2010). These sources do not agree on all cities enjoying membership and generally refer to the membership as it existed in the fifteenth century, rather than employing measures more proximate to the eve of the Reformation. 
Reformation does not appear to have resulted from a sudden shift toward Protestantism once a "critical mass" of adopters had been reached but rather suggests a steady rate of adoption as Protestantism diffused across the HRE.

The uneven pattern of adoption among Hanseatic cities may be understood in terms of the relational structure of the league. Every city had to determine the contentious issue of unseating the Roman Church in favor of Protestantism. But this does not mean that membership in the league had no effect on the process of deciding. It is not that the individual traits of Hansa towns similarly disposed them toward Protestantism but rather that the relations among them facilitated the diffusion of "evangelical" ideas and enabled the social influence that made the adoption of Protestant reforms more likely. Analyzing a large sample of cities, we propose that the network relations between Hansa cities increased their odds of reform compared with other cities and predict which Hansa members would reform and which would remain Catholic.

The present article is the first study of the Protestant Reformation using social network data (except Tulchin 2010). We have assembled new data for Hansa towns regarding their participation in Hansa Diets and merged these with the data set collected by Rubin (2014). We reveal the importance of social relations in the adoption of the Protestant Reformation and why the structure of relations among Hanseatic towns was especially favorable to diffusion. We propose that the social relations between Hansa towns as generated by their participation in Hansa governance facilitated the exchange of Protestant ideology and exerted an influence on highly involved members to adopt reform. While other studies on the adoption of the Reformation emphasized power dynamics and imitation (Cantoni 2012) or the importance of change agents as brokers (Kim and Pfaff 2012), we highlight historical embeddedness of elites during times of uncertainty as an additional social explanation for complex diffusion. Our study differs from the previous ones by emphasizing the importance of strong and weak ties across regions established before times of institutional change such as the early stage of the Protestant Reformation.

\section{Social Networks and Complex Diffusion}

Geographers have begun to use network methods to understand the various patterns of associations between towns in Europe using quantitative data (e.g., Rozenblat and Melançon 2013). The centrality of a town within the urban network not only depends on various factors such as population size, but also on the activities and characteristics of personnel (Comin 2013). While density and connectivity between towns, regions, and countries has likely increased over time using new technologies (Castells 1996) and global economic markets (Sassen 1991), the integration of European networks is not a new phenomenon. Towns in the HRE have been connected through Hansa traders at least since the Middle Ages (Simmel 1992 [1908]), but studies of town networks and diffusion in the early modern period have been rare.

Sociologists have studied the adoption of new products and behaviors for a long time and often focused on specific elite groups such as doctors or managers. A common key feature of innovations is the uncertainty related to the consequences of adoption. 
Social contacts such as colleagues may mitigate uncertainties and thereby influence the adoption process (e.g., Coleman et al. 1957). Among network scholars, the problem of uncertainty has been theorized most prominently by Granovetter (1985) who points to the importance of network ties and "social embeddedness" for economic action. One of the key ideas is that if economic actors are uncertain about the quality of goods and services, they prefer information from close contacts (strong ties) - those with whom they have repeated interactions-over those from acquaintances (weak ties). Yet doing so can produce negative consequences, as one's close contacts often provide redundant information (Granovetter 1973). While the famous strengths of weak ties argument relates information flows in social networks to the intensity of social interactions, strategic actors may actively generate their network positions by adding and deleting network contacts and thereby gain better positions in markets. Burt (1992) argues in his "structural holes theory" that actors who have otherwise unconnected social contacts may gain advantages if they act as brokers. Brokers who have many social contacts that are not connected among each other have better access to information and could benefit from having a knowledge advantage. Benefits can also be gained if information or other resources are controlled by strategic actors who position themselves between others. Structural holes theory posits that it is the structure of social relations that has a causal impact on the flow of information among actors-rather than the strength of ties. Actors with "sparse" networks have more access to and can better control the flow of information compared to actors with dense networks. For instance, towns whose connections are limited to a cohesive cluster tend to have less access to new market information compared to towns engaged in multiple regions including foreign places.

An important extension of this line of thought was made by Centola and Macy (2007), who point out that Granovetter's weak tie argument may be limited in scope. In particular, many types of collective behavior entail different levels of cost and risk that cannot be established through simple information transfer. Weak ties may be effective but only in simple contagions with low thresholds of infection, such as disease transmission or information exchange. Complex contagion, by contrast, is when costs and risks are higher and individuals have higher thresholds of adoption. The adoption of the Reformation, whose benefits were diffuse and that entailed substantial political and economic risks, is an obvious example of the complex contagion problem.

According to Centola and Macy, complex contagions are more demanding on the network insofar as multiple sources are required to provide sufficient affirmation or reinforcement to lead to adoption. They further underline the subtle distinction between "multiple exposures" such as repeated contacts with the same individuals and "exposure to multiple sources," which refers to contacts with more than one person who has adopted a behavior (ibid.: 707). To trigger adoption in complex diffusion, individuals need to have "multiple sources of activation"-what they also call "wide bridges." Centola and Macy (ibid.: 729) conclude that "complex contagions may favor spatial networks not only because the ties between nodes are physically short but also because the bridges between neighborhoods are structurally wide. While spatial proximity can make the connection relationally strong, it is the width of the 
bridge that makes the connection structurally strong for the propagation of complex contagions."

While social relationships may span across neighborhoods, network ties may also connect economic organizations across regions. Davis and Greve (1997) consider the role of network ties and geographical proximity by examining the adoption of two initially controversial governance practices. They underline the importance of "legitimacy" and perceptions of "acceptability" among decision makers for the spread of practices and structures. Using data on corporate interlocks and business location, the authors find variation in the adoption of business innovations. They conclude that "both the social ties among firms - structural embeddedness - and the norms of directors - cultural embeddedness - conditioned how quickly and in what direction the field of large corporations adapted" (34).

Davis and Greve discuss cultural and structural embeddedness as distinct entities with different effects on diffusion processes. Their perspective may neglect how culture and politics are results of social relations developed in the past. Zukin and DiMaggio (1990) highlight the interpersonal context of economic action, particularly patterns of repeated network ties. They emphasize cultural and political embeddedness, defined as the manner in which economic institutions and decisions are shaped by shared meanings and the struggle for power in the state and between social classes. Cultural embeddedness may be particularly important in explaining "long-term or dramatic historical change" (17), such as the Reformation.

More recent literature picks up on dynamic aspects of diffusion, showing how network topologies, interaction patterns, and individual locations are not constant, but change over time. Centola (2015) analyzes the association between network origins and complex diffusion. Rather than being driven entirely by the efficient spread of information through weak ties, complex diffusion is facilitated by social structures in which groups enjoy moderate levels of consolidation and in which group members have many cross-cutting social ties. Social structures of this kind provide enough social homophily to create meaningful collective identities without being so cohesive as to eliminate extralocal ties. Societies with high levels of consolidation show high correlations between social categories so that an individual's position in one category allows us to predict her position in another. For instance, knowing someone's neighborhood may lead to an accurate prediction of her occupational class in a highly consolidated society.

Using network simulations, Centola finds that societies with high consolidation are poorly integrated across groups in terms of shared norms and practices, as the underlying network structure produces highly segregated communities. Reduced consolidation increases the number of cross-cutting ties across social circles that enhance social diffusion. However, if consolidation is very low and networks are highly intersecting, diffusion of practices and norms may fail due to the underprovision of social support and reinforcement for adoption. Complex social diffusion is most likely if a society is moderately consolidated.

We argue that complexity in diffusion is not restricted to the risks and uncertainties related to the innovation or new practice, but also to the ways network ties affect 
the diffusion process. Recent literature on intraorganizational teams has begun to link network topologies to the experiences of the actors with each other in past interactions. Grund (2016) finds that team players who know each other from past interactions tend to interact more frequently with each other. Network experience positively impacts patterns of interactions in teams. Such experiences may affect complex social diffusion as well. Network experiences in dyadic interactions have similarities to the strength of ties.

Trust networks were at the origins of European cities (Blockmans 2010). Strong ties have the advantages of including trust that is important when reinforcement is necessary in complex diffusion. Studies on network diffusion focus on the processes during the spread of an innovation and ignore the quality of past interactions. Interactions are historically embedded with cognitive, cultural, social, and political content. Organizational age and repeated interactions before an event provide the relational foundations (including cultural and political embeddedness) that enhance complex diffusion. Past collaborations and alliances provide affirmation and social reinforcement and could affect the collective adoption of a new practice. Historical embeddedness matters for complex contagions and institutional change.

\section{Hypotheses}

While previous research has shown that Hansa membership is associated with the adoption of the Reformation, we focus on the relational structure of the medieval Hansa. Based on research on diffusion in social networks (Davis and Greve 1997) we expect that if the Hansa organization was important for diffusion in the early stage of the Reformation, then its network structure would be characterized by high density. Moreover, according to Centola (2015), complex diffusion works best in networks that show some amount of clustering but that are not totally segregated.

Hypothesis 1: The Hansa network of towns is expected to show high density, medium amounts of clustering, and small characteristic path lengths.

Based on the literature on networks and diffusion, our general prediction is that more "central" towns in the Hansa network will be more likely to adopt the reform using mechanisms such as information flow, social influence, and reinforcement. How we define central and how this relates to adoption is specified in a set of hypotheses testing different network mechanisms through different network measures.

Generalized Centrality. Generalized centrality measures "enable researchers to set the relative importance between the number of ties and tie weights" (Bonacich 1987; Freeman 1978; Opsahl et al. 2010: 246). Generalized degree centrality captures the involvement of a node (i.e., a connection point) in the network. Opsahl et al. (2010) argue that the involvement of a node in a network can be measured either by counting the number of ties in a binary network or by taking the sum of the weights in a weighted network considering the frequencies of interactions. To take both aspects 
into account, Opsahl et al. develop a generalized degree measure with a tuning parameter, $\alpha$, regulating the relative importance of each. Closeness and betweenness centrality identify and measure lengths of the shortest paths in a network. The assumption is that actors relationally closest to all others receive information faster, which may have advantages in decision making. Similarly, actors located between many others may better control information flow to the extent that they are located on shortest paths. Communication can spread using multiple paths simultaneously as information is often divisible (Borgatti 2005; Estrada 2012: 142). Opsahl et al. (2010) point out that longer chains of strong ties may spread information faster than shorter weak ties and that transmission is more probable if interactions are more frequent. The quality of resources flowing through paths with fewer intermediaries is likely higher compared to paths with more intermediaries. This complexity in the relative weight in numbers of ties and tie strength is also captured by a tuning parameter $\alpha$ in generalized closeness and betweenness measures.

Our hypotheses regarding the complex association between tie strength and numbers of ties are linked to the tuning parameter that varies between 0 and 2. When the alpha parameter is close to either 0 or 1 then the tie weights or the number of ties are irrelevant, respectively. If $\alpha$ is set to 0 , the generalized measure equals Freeman's (1978) measure using a binary network and tie weights are not considered. If $\alpha$ is set to 1 , the generalized measure captures tie weights only, but not the number of ties. Other values of the tuning parameter $\alpha$ consider combinations of both numbers of ties and tie weights. In the range between 0 and 1, numbers of ties and weights are positively valued. For values higher than 1 , the tuning parameter gives negative values to number of ties and positive values for tie strength (Opsahl et al. 2010: 250).

While our measures do not allow us to capture previous exposure by other network partners, which has been found to be relevant for diffusion (Valente et al. 2015), generalized degree measures better capture the features of the local network structures of towns and can therefore better predict the network susceptibility of a town compared to classical centrality measures. Following Centola (2015), we expect that towns that not only are embedded in clusters but also show many connections beyond these are more likely to adopt reform compared to other towns. While a "good mix" of strong and weak ties may reduce the likelihood of overembeddedness (Uzzi 1997), we argue that tie weights are slightly more important in the context of the networks derived from Hansa event data. Applied to the generalized centrality measures this means that tie weights are relatively more important than numbers of ties. This is related to the fact that tie weights capture the interactions between towns at Hansa Diets that could lead to the spread of important information regarding the Reformation.

Hypothesis 2: The more frequently a town attends Hansa Diets and the higher the number of towns it is connected to, the more likely reform is adopted: Optimal tuning parameter for generalized degree centrality is expected to be $0.5<=\alpha<1$, which captures the fact that tie weights are more important than numbers of network ties. 
Hypothesis 3: Towns with longer paths composed of stronger ties are more likely to adopt reform compared to towns with shorter and weaker ties: Optimal tuning parameter for generalized closeness and betweenness centrality is expected to be $\alpha>1$, which captures the fact that tie weights are more important than numbers of paths.

Generalized Degree Centrality. We expect a positive association between involvement in the Hansa network and the adoption of the Reformation. Net of the common social, economic, and political variables that have been used to explain the Reformation, we expect that the greater the involvement of a city with other members of the Hansa organization, as measured through joint participation in diets, the greater its odds of adopting Protestantism.

Hypothesis 4: The higher the involvement of a town in the Hansa town network (degree centrality), the more likely the town adopts the Reformation by 1530.

Closeness and Centrality. While degree centrality offers a powerful and intuitive way to capture the involvement and activity of a node in a network, it is limited insofar as it only captures the neighborhood of a node. Other measures such as closeness and betweenness centrality consider information about the total network (Freeman 1978; Opsahl et al. 2010: 245). We believe that both measures may have been relevant for adoption of reform. Closeness centrality captures relational distances between towns. Towns that are relatively close to other towns in terms of relational distance could get new information quicker as information travels through the shortest paths. Conversely, towns that already have information could distribute information faster if they are closer to other towns on average (Estrada 2012: 140; Freeman 1978). Using optimal tuning parameters, we can see whether the shortest paths were most important or whether longer, "thick" paths contributed more to Protestant adoption.

Hypothesis 5: The shorter the relational distance of a town to other towns in the Hansa network (closeness), the more likely it adopts the Reformation by 1530 .

Another classical measure, betweenness centrality, captures brokerage aspects. Towns in structural locations between other towns may either promote or impede communication between nodes. The fraction of information that goes through a town may be higher if it is positioned on many short paths between towns. Whether the shortness of paths mattered relative to thick ones is also an empirical question.

Hypothesis 6: The higher the brokerage potential of a town in the Hansa network (betweenness), the more likely it adopts the Reformation. 


\section{The Case: Complex Diffusion and the Protestant Reformation}

Why would an organization of practical, worldly traders like the Hansa have facilitated the diffusion and adoption of Protestantism at all? One school of thought in explaining the Reformation suggests that demands for greater piety, a reformulation of communal ritual and public morality, broader inclusion, and greater clerical accountability drove the Protestant movement to challenge the political and ecclesiastical establishment in many cities (Blickle 1992; Mörke 2005; Ozment 1975; Postel 2006). Another school of thought emphasizes how the contending political interests of burghers, urban patricians, and regional princes decided the issue of the urban Reformation (Brady 1998; Dixon 2000; Schubert 1996; Tracy 1986).

Trade and commercial development was another substantial factor. In the Germanspeaking towns of the HRE where Luther's movement first took foot, long-distance trade had mushroomed since the twelfth century. Besides land-based trade, much of which was directed toward Italy, there was a great upsurge of trade in the Baltic and the North Sea regions. Hansards were mercantile capitalists who profited by carrying mostly small cargoes to retail centers that stretched northward to Bergen in Norway, westward to Bruges and London, and eastward to Novgorod. Hansards coordinated security from piracy and predation, set prices, and controlled the output of key commodities.

The eminent Reformation historian Heinz Schilling (1983) sees the Hanseatic cities as standing forefront of the early Protestant movement because of favorable internal conditions; a mixture of ambitions toward greater civic autonomy from the territorial princes; struggles between burghers and patricians; and latent anticlericalism. Schilling goes so far as to argue for a "special type of Hanseatic City Reformation" (444). He proposes that robust institutions of civic governance and de facto autonomy from regional princes made Hansa towns eager to assert their prerogatives and open to influence from the middling class of citizens (445). If so, then Hansa cities would be comparable to the free and imperial cities that have long been shown to have been especially prone to adopt Protestantism for the same reasons (Moeller 1972).

The main difference between Hansa cities and other self-governing towns stemmed from the extent of their involvement in trade, which generated the prosperity that made independent action possible. As Schilling (1983: 453-54) notes, this autonomy was crucial for the early Protestant breakthrough: "In the earliest stage of the North German Reformation the religious and political lines were quite clear... all the territorial rulers took the side of the old church. Consequently, a successful Lutheran Reformation meant at least demonstration of municipal independence from territorial tutelage, in most cases even a real short-term expansion of the town's autonomy based on the medieval tradition and privilege." More recently, Rubin (2014: 272) also suggests that the Hansa towns were more prone to reform because of relatively open polities, noting that: "In the northern Hanseatic cities, it was largely the middling bourgeoisie, who were wealthy but had little political power within the cities, which encouraged the Reformation as a means of confronting the established powers." 
Other historians have rejected Schilling's argument noting that, although some Hansa towns such as Hamburg eagerly embraced the Reformation, others, such as Lübeck, came to it tentatively and despite much elite hostility (Postel 2006). A few, such as Cologne (the "German Rome"), remained resolutely Catholic (Scribner 1976). A leading historian recently declared that there is no Northern pattern in the response to Protestantism at all: "The introduction of the Reformation in the Hanseatic cities was not achieved at the same time, in the same way, or under the same conditions. Every city determined the matter itself" (Postel 2009: 138-39). The northern cities were simply predisposed toward the ideas of Luther and his followers by virtue of their social structures and commercial development (Postel 2006).

To understand how the Hansa is implicated in the diffusion and adoption of Protestantism, it is necessary to consider the history, institutions, and incentives that informed the reaction to the early Reformation. The Hansa began with the establishment of Lübeck as a city in the middle of the twelfth century. It became the "head" of the organization as the main coordinator of common activities, including the negotiation of trade privileges in foreign lands and peace treaties with foreign rulers or rival towns. Lübeck also became the host of most of the gatherings of the league, the Hansa Diets, to which members sent representatives and that met regularly from 1358 through 1669.

Hansa Diets governed the organization's foreign trade outposts (Kontore) and set trade policies. Most of the delegates were city councilors from their respective cities and active or former long-distance traders. Delegates at Hansa Diets were likely members of a Hansa elite that not only had access to the councils in one city but also in other Hansa towns. These men were not only political representatives but often relatives and friends to each other, linked by ties of kinship, marriage, and business (Poeck 2010). Relations between Hansa delegates involved trust based on family ties or repeated interactions in multiple domains such as trade and politics. As city councils in central Hansa towns like Lübeck showed high levels of closure based on co-optation (e.g., Peters 1939), it can be argued that the institution of Hansa Diets was relatively stable and its character persisted over time.

Nevertheless, in the early sixteenth century, the Hansa was coming under enormous pressure, chiefly as a consequence of the rise of ambitious territorial states, but also as a result of growing differences among its members (Postel 2009; Seier 2012). The Hansa lost members who had failed to maintain trade privileges or lost their political autonomy to rising territorial princes. At the same time, maintaining exclusive trade privileges abroad, the other key component of Hansa organization, was becoming outmoded as a way of doing trade in the sixteenth century. As the center of northern trade shifted from the Baltic and the North Sea to the Atlantic, the domination of many trading centers by German merchants was increasingly resented (Tawney 1954 [1926]: 63). Despite the efforts of the Hansards to maintain ethnic exclusivity in trade, foreign rulers began to close Hansa trade centers and eliminate their privileges in favor of their own local mercantile groups. 
Hansa leaders tried to reform the organization in response to these challenges to become a stronger and more effective confederation of cities (Selzer 2010). The outbreak of the Protestant movement occurred at the same time as these efforts to reorganize the Hansa (Hammel-Kiesow 2008: 110; Seier 2012). The Lutheran movement posed a challenge as confrontational and disruptive groups within the towns insisted on ecclesiastical and secular reforms. In July 1525, the Hansa Diet meeting in Lübeck passed a resolution restating its rejection of the "dangerous sects" inspired by Luther (Postel 2009: 131-32). Echoing the condemnation and repressive measures announced in the 1521 Edict of Worms announced by Emperor Charles $\mathrm{V}$, the organization's delegates resolved to ban the printing and sale of Luther's works; forbid Protestant preaching and house churches; and insist on the retention of Catholic priests and sacraments. Offenders would be punished by imprisonment or exile.

This resolution marked the first time that questions of faith had ever been taken up as part of the official agenda of the Hansa, a reflection of the extent to which Hansards feared Protestantism's manifold "threats to the ecclesiastical and secular order" and to the league's unity (ibid., 132). Protestant reforms threatened the preponderance of the patricians and the mercantile elite that had dominated the Hansa, and they were potentially bad for long-distance trade. Nevertheless, popular pressure compelled a number of Hanseatic cities, including Hamburg, to adopt Lutheran reforms in the early 1520s (Postel 2009).

Why would the Hansa as an institution have come out against the Protestant movement so forcefully, particularly when it had already made substantial inroads in some important members such as Hamburg and Rostock (Postel 2006)? There are two apparent reasons. The first has to do with the threat to trade posed by religious disputes that, in the context of the sixteenth century, inevitably must become political conflicts. As the emperor and pope opposed Luther's movement, the adoption of Protestantism might cause costly confrontations or interruptions of trade. Being seen on the side of the new heresy might compromise the interests of Hansards not only in the empire but also abroad. Protestant partisanship invited embargo or retaliation and could endanger merchants in foreign ports hostile to Luther (Veltmann 2005). To the extent that reform movements created uncertainty and discord among cities and territories, prudent businessmen would tend to oppose them.

Second, the Hansa model was predicated on coordination among member cities to enforce a commercial policy that established exclusive trading privileges; enforced retail monopolies; forbade credit and joint ventures with outsiders; and defined standard weights, measures, and product lines. In his discussion of the Hansa, Weber (1981 [1927]: 235) notes that "[i]ts internal policy was directed toward the dominance of a market aristocracy, and especially in the sense of suppressing the craft guilds." A movement "from below" must have seemed a threat to the elite interests upon which was premised the functioning of the Hansa.

In fact, the Protestant movement triggered a political crisis. Like all medieval German cities, the Hansa towns were oligarchical republics dominated by wealthy 
patricians and leading merchants (Korell 1980: 33). The Hansa organization may have been so hostile toward the Reformation because of the adversarial way in which it was introduced in many towns; a contentious Protestant movement embraced by the "middling classes" of burghers, and especially by guildsmen, directed against the ruling oligarchies and demanding inclusive reforms (Blickle 1992; Brady 1999; Scribner 1986; Te Brake 1998).

Despite the hostility of the Hansards, the movement quickly reached the "common man" in the North German towns. The spread of Reformation ideas was hastened by noisy preachers and public sermons, often held outside of churches and beyond the town wall (Scribner 1984; Veltmann 2009: 148-49). An important theme of this preaching, and of subsequent pamphlet publishing, was the use of the local Low German (Plattdeutsch) language in preaching and worship, which was pitched as the idiom of the common folk of the city. Schilling (1983) observes that members of the Hansa, with their "many transterritorial connections" not only had extensive social ties to each other but were developing a common culture, making them prone to mutual influence. Asche (1999) reveals a distinctive Low German Kulturraum in the sixteenth century that united many Hansa towns. This culture was characterized by a distinctive regional language; patterns of trade and business relations; intermarriage; and, for long-distance traders, formative experiences as foreign merchants living abroad in socially encapsulated Hanseatic trading enclaves (the Kontore) (Pichierri 2000; Selzer 2010).

Hansa towns not only demonstrated the interaction patterns between towns based on homophily (e.g., regional proximity, similar trade goods, kinship relations in councils and trade, similar economic and political interests) but also consolidation (e.g., options for mobility), and therefore offered the perhaps ideal network structure for complex diffusion such as the Protestant Reformation. Medieval towns were moderately segregated so that different occupational groups, for example merchants and craftsmen, lived in different parts of the towns. However, city councilors and wealthy merchants usually lived in prestigious streets close to the town hall. Hansa towns often allowed social mobility, something that is not very common in other regions. Jahnke (2014) shows how fraternities, marriage, and business contacts helped new men move up the social ladder and into the city council. Compared to the contemporaneous Italian city-states with closed elite groups (Puga and Trefler 2012), there was much more openness in Hansa towns, another condition that is favorable to complex diffusion (Centola 2015).

\section{Data and Methods}

To assess whether social networks among Hansa towns mattered for the early diffusion of the Reformation we calculate descriptive network measures of the total cumulative Hansa town network from 1492 to 1516 . We treat the position of Hansa towns within the Hansa network as city attributes and evaluate the extent to which a town's network 
TABLE 1. Descriptive statistics

\begin{tabular}{|c|c|c|c|c|c|}
\hline Variable & Obs & Mean & Std. Dev. & Min & $\operatorname{Max}$ \\
\hline Protestant Reform by 1530 & 753 & 0.11 & - & 0 & 1 \\
\hline $\operatorname{Ln}(\mathrm{Pop})$ & 753 & 1.74 & 0.9 & 0 & 5.42 \\
\hline Press & 753 & 0.23 & - & 0 & 1 \\
\hline Market Potential & 753 & 19.32 & 6.54 & 5.92 & 85.9 \\
\hline Ln(DistWitt) & 753 & 6.18 & 0.76 & 3.04 & 7.27 \\
\hline Ln(DistZurich) & 753 & 6 & 0.64 & 2.52 & 7.04 \\
\hline Independent City & 753 & 0.06 & - & 0 & 1 \\
\hline Lay Magnate & 753 & 0.88 & - & 0 & 1 \\
\hline Bishop & 753 & 0.31 & - & 0 & 1 \\
\hline Water & 753 & 0.65 & - & 0 & 1 \\
\hline University & 753 & 0.07 & - & 0 & 1 \\
\hline Hansa Membership & 753 & .08 & - & 0 & 1 \\
\hline Degree Generalized $(\alpha 0.5)$ & 753 & 0.39 & 2.63 & 0 & 29.29 \\
\hline Betweenness Generalized ( $\alpha 0.1$ ) & 753 & 0.22 & 2.57 & 0 & 45.27 \\
\hline Betweenness Generalized ( $\alpha$ 1.1) & 753 & 0.52 & 5.36 & 0 & 88.78 \\
\hline Closeness Generalized ( $\alpha$ 2.0) & 753 & 1.05 & 11.46 & 0 & 164.22 \\
\hline
\end{tabular}

position affected its likelihood of reform. Descriptive statistics for all variables are provided in table 1, and their Pearson's correlation coefficients are reported in table 2.

\section{Dependent Variable: Reform}

To test our hypotheses, we examine the propensity of cities in central and Western Europe to institute reforms up through 1530 . Our study is limited to the early Reformation, from 1517 to 1530 , the period in which religious reform was driven by an urban social movement and in which the interests of territorial rulers played the least role in determining whether towns adopted the Reformation (Blickle 1992; Moeller 1972; Mörke 2005; Postel 2006, Scribner 1986; Te Brake 1998). Our dependent variable and control variables are drawn from Rubin's data set (see Rubin 2014 for further details on these measures). The dependent variable is coded 1 for cities that are Protestant in 1530 and 0 otherwise. This variable was coded from historical atlases and the Catholic Encyclopedia (ibid.). A city receives a value of 1 "if it accepted the Augsburg Confession, Catholics were forced to flee, or the encyclopedia explicitly states the Protestantism was accepted" (ibid.: 283).

\section{Independent Variables}

Hansa Network. Our network measures are generated from Poeck's (2010) list of Hansa delegates and towns attending Hansa Diets. ${ }^{3}$ Poeck's list includes 34 towns form. 
TABLE 2. Pearson's correlation coefficients

\begin{tabular}{|c|c|c|c|c|c|c|c|c|c|c|c|c|c|c|c|c|}
\hline & 1 & 2 & 3 & 4 & 5 & 6 & 7 & 8 & 9 & 10 & 11 & 12 & 13 & 14 & 15 & 16 \\
\hline 1. Protestant Reform by 1530 & 1 & & & & & & & & & & & & & & & \\
\hline 2. $\operatorname{Ln}(\mathrm{Pop})$ & -.17 & 1 & & & & & & & & & & & & & & \\
\hline 3. Press & -.02 & .44 & 1 & & & & & & & & & & & & & \\
\hline 4. Market Potential & -.13 & .17 & .16 & 1 & & & & & & & & & & & & \\
\hline 5. Ln(DistWitt) & -.39 & .13 & -.09 & -.24 & 1 & & & & & & & & & & & \\
\hline 6. Ln(DistZurich) & -.12 & -.04 & -.25 & -.57 & .46 & 1 & & & & & & & & & & \\
\hline 7. Independent City & .22 & .13 & .12 & .1 & -.19 & -.36 & 1 & & & & & & & & & \\
\hline 8. Lay Magnate & -.18 & -.12 & -.17 & -.17 & .23 & .35 & -.66 & 1 & & & & & & & & \\
\hline 9. Bishop & -.13 & .39 & .34 & .01 & .17 & -.07 & .03 & -.18 & 1 & & & & & & & \\
\hline 10. Water & .08 & .07 & .18 & -.02 & -.13 & -.13 & .07 & -.01 & .08 & 1 & & & & & & \\
\hline 11. University & -.06 & .34 & .37 & .04 & .03 & -.05 & -.02 & -.01 & .25 & .09 & 1 & & & & & \\
\hline 12. Hansa Membership & .23 & .07 & .05 & -.03 & -.36 & -.00 & .11 & -.18 & -.04 & .04 & -.00 & 1 & & & & \\
\hline 13. Degree Generalized $(\alpha 0.5)$ & .23 & .12 & .09 & -.03 & -.19 & .01 & .19 & -.15 & .02 & .07 & .03 & .49 & 1 & & & \\
\hline 14. Betweenness Generalized $(\alpha 0.1)$ & .21 & .09 & .1 & -.03 & -.12 & .01 & .22 & -.15 & .06 & .05 & -.02 & .29 & .77 & 1 & & \\
\hline 15. Betweenness Generalized ( $\alpha$ 1.1) & .16 & .12 & .13 & -.01 & -.11 & 0 & .23 & -.2 & .09 & .03 & .03 & .32 & .73 & .81 & 1 & \\
\hline 16. Closeness Generalized $(\alpha 2.0)$ & .2 & .09 & .09 & -.05 & -.13 & .02 & .13 & -.07 & .01 & .06 & .03 & .30 & .89 & .78 & .65 & 1 \\
\hline
\end{tabular}


attending 29 events in the period from 1492 to 1516 . Towns are attending 5.74 events, on average, with a standard deviation of 7.99, a minimum of 1 , and a maximum of 26 events. Average attendance at events is 6.93 towns with a standard deviation of 4.24. The smallest event has three towns and the largest event has 23 towns.

The cumulative Hansa town network shows a connection between towns through joint participation at one or more Hansa Diets in the 25-year period before 1517, the year of the Reformation. Town-by-town networks are one-mode projections derived from shared affiliations of Hansa delegates "representing" Hansa towns at Hansa Diets (Breiger 1974). Poeck's data include information about how many events each pair of towns has attended, and how many other towns attended these events. This information is used to estimate the strength of collaborations between towns following Newman's (2001) procedure for weighted collaboration networks. Higher weights are assigned to repeated collaborations and collaborations of smaller size (Opsahl 2013).

To characterize the total Hansa town network, we first calculate topological properties following Centola (2015: 1312). For the cumulative social network of towns represented by individual delegates at Hansa Diets from 1492 to 1516 we calculate a clustering coefficient and path length. Other characteristics of the total network related to diffusion are calculated as well, for example density, diameter, cohesion, and centralization. ${ }^{4}$

To describe the structural locations of individual towns in the cumulative Hansa town network, we calculate a set of "centrality scores" that distinguish nodes from each other (Freeman 1978; Robins 2015: 183; Wasserman and Faust 1994: 169ff.). Nodes that are not in the Hansa network have a centrality score of $0 .^{5}$ Prominence or activity of town is measured as "degree centrality" that captures the numbers of connections for each town. "Betweenness centrality" captures brokerage potential and the importance of towns for connecting the Hansa network using short paths. "Closeness centrality" is a measure for relational distance that sums the shortest paths between a Hansa town and all other towns.

While the previous measures apply to binary networks and merely distinguish between absence and presence of a relationship between nodes, more refined centrality scores can be calculated for weighted networks. Opsahl et al. (2010) propose a generalized degree measure that considers numbers and weights of ties. This measure captures how strong the ties of a node are to other nodes and how many connections or different paths it has. Moreover, the authors develop a shortest distances algorithm and refine closeness and betweenness measures by considering numbers of intermediaries and weights of ties. This has special implications for diffusion in networks, according to Opsahl et al., if networks include strong ties. For instance, in some situations short

4. As these are standard measures, we refer to the standard literature on network methods such as Wasserman and Faust (1994). For these and other network calculations and visualizations we used the R packages "igraph" and "tnet."

5. There was also a set of Hansa towns in Rubin's (2014) data that did not attend Hansa Diets during the time of observation as recorded in Poeck's (2010) list. Conversely, Poeck's data include towns that were not included in Rubin's data, for example smaller towns. For network calculations, we considered all Hansa towns included in the Poeck data. In statistical analyses, Hansa towns that were not recorded in Poeck's list were assigned a 0 like other non-Hansa towns. 
paths of weak ties (of length 1) may be slower and less likely for information flow compared to longer paths of strong ties (of length 4). Based on these weighted onemode networks of Hansa towns, we calculate second-generation centrality measures (ibid.). Using second-generation centrality measures is a useful strategy as the number of ties, the basis of Freeman's (1978) measures, may not be as important as having strong ties in complex diffusion. We calculate generalized degree centrality measures considering numbers of ties and tie weights. The relative importance of these is determined by an optimized tuning parameter. To find the optimized tuning parameter alpha, we calculate maximum significance levels of alpha in probit models predicting adoption of reformation in a sample of 63 Hansa towns. Similarly, we calculated closeness and betweenness centrality using Opsahl et al.'s (2010) second-generation measure for weighted networks including corrections for disconnected components. Optimal tuning parameters were also calculated for these.

\section{Control Variables}

Hansa Membership. This variable is coded as 1 if the town is a member of Hansa and 0 otherwise as identified by Dollinger (1970, 1989).

Printing Press. We control for the presence of a printing press in a city, as this has been found to have facilitated the adoption of Protestantism (Rubin 2014). This variable is coded as 1 if there was a printing press in a city prior to 1500 as identified in either Febvre and Martin (1958) or Clair (1976).

LN (natural logarithm) Population. As is standard in early modern historical analysis, we use population size as a proxy for a city's economic development. Population size is measured in thousands of persons, which is logarithmically transformed. The population data came from Bairoch (1988) either for the year 1500 or from linearly interpolating the population using data from prior to 1500 or from data after $1500 .{ }^{6}$

Market Potential. We also control for market potential, which captures a city's proximity to large cities. It is "the sum of other city's population divided by their distance to the city in question" (Rubin 2014: 275).

Distance to Wittenberg and Zurich. Previous studies have shown that, net of local conditions, ideological influence through spatial diffusion helps explain whether cities in the HRE adopted Protestantism (Becker and Woessmann 2008, 2009; Pfaff and Corcoran 2012; Rubin 2014). To capture the spread of demand for both the Lutheran and Zwinglian branches of the Reformation, we calculate the distance of each city 
to both Wittenberg and Zürich. ${ }^{7}$ The distance to Wittenberg and distance to Zurich variables were logarithmically transformed. Because these variables are generated based on Wittenberg and Zurich, both cities were excluded from the models. ${ }^{8}$

Political Regimes. Previous studies have shown that civic autonomy, and especially freedom from princely or ecclesiastical interference, helped to determine if a city adopted Protestantism. Prior scholarship suggests that free and imperial city-states (Reichs-und Freistädte) tended to favor the Reformation (Moeller 1972). As such, we control for a binary variable in which 1 represents an "independent Free Imperial City in 1517" and 0 otherwise (Rubin 2014: 275). The independence of a city was determined based on Jacob (2010). We also include a binary variable for whether a city was a part of a "lay" magnate (it was neither free nor subject to an ecclesiastical lord) and a binary variable for whether a bishop or archbishop resided in the city by 1517 (Cheney 2017).

Water. We control for whether a city is on a body of water $(1=$ yes, $0=$ no), which can affect the diffusion of information. Data for this variable "were collected by searching Google Maps and determining each city's access to water" (Rubin 2014: 284).

University. Lastly, we include a control for whether the city has a university by $1450(1=$ yes, $0=$ no $)$.

\section{Data Limitations}

While the historical records from the Hansa Diets 1492-1516 give us a deeper understanding of the cumulative relational structure of the Hansa political network until the eve of the Reformation, we lack information about the network structure of the medieval Hansa during the actual adoption period as well as detailed information on the year of adoption in each city. The available data limit our analyses to a crosssectional model. Using panel data from a later period, Cantoni (2012) examines the dynamic aspects of adoption as being partly driven by the adoption of neighboring regions.

Our network measures may overestimate the embeddedness of towns that stopped attending Hansa events after our period of observation. However, we believe that changes in the Hansa network are small in our period of investigation that ended in the year 1530. Data limitations do not permit us to disentangle the problem in diffusion studies identified by Burt (1987) in that adoption could be caused by cohesion or structural equivalence. Towns may have reformed because towns with similar trading partners, allies, or enemies outside the Hansa have done so. Finally, Nyköbing in

7. Distances "were calculated as the crow flies, using city coordinates and the distance formula (and translating degrees into miles)" (Rubin 2014: 285). Bairoch (1988) identified the city coordinates.

8. Because Mainz was "the birthplace of printing" (Rubin 2014: 271), it was also excluded from the sample. 


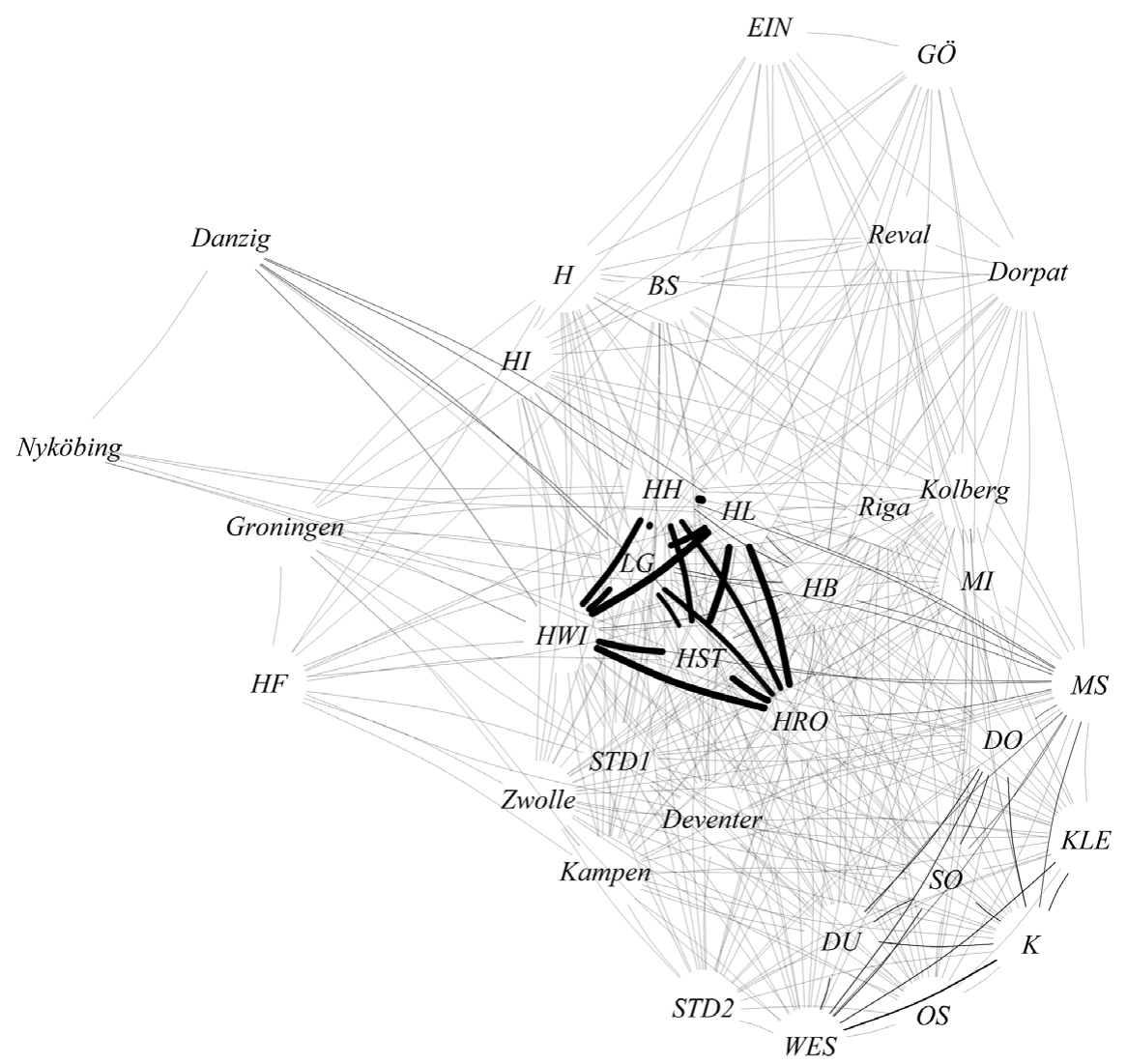

FIGURE 1. Cumulative Hansa town $\times$ town network 1492-1516, weighted edges. German towns are labeled using their official German license tag. Names of nonGerman towns are written in full words.

Sweden was not a Hansa town but rather was the contemporaneous seat of the Swedish crown. It was included in the network because of the close ties between the Swedish monarch and the Hansa, its hosting of a Hansa event, and the interactions it fostered between Hansa towns. For similar reasons, we include a few Hansa towns that attended events but left the Hansa afterward.

\section{Results}

Topology of Hansa Network and Positions of Hansa Towns

We use descriptive network measures to assess the cumulative Hansa network in the 25-year period before the Reformation. In figure 1 , we depict the town $\times$ town network with weighted edges using Newman's (2001) procedure for weighted 
collaboration networks. The network includes 34 Hansa towns connected through 29 Hansa events. Towns with a high number of shared events may be characterized as having "strong ties," and towns with only a few interactions in the 25-year period are linked through weak ties (e.g., Granovetter 1973). We observe that all Hansa towns listed by Poeck (2010) for the period from 1492 to 1516 are connected into a single network component. Non-Hansa towns may be considered as isolates because they did not attend Hansa events. Not all towns have the same number of connections as indicated by the number of lines. Some towns have a higher centrality in the Hansa network. Some actors also seem to show equivalence in positions constituting "social roles" (Hanneman and Riddle 2011: 341).

Hansa towns varied strongly in numbers and types of events they participated in, for example location and size of events. Consider the position of Hamburg (HH in Figure 1), which was perhaps the center of the Reformation in Northern Germany relative to the position of Cologne, which remained Catholic. The graph in figure 1 locates Cologne $(\mathrm{K})$ at the periphery whereas Hamburg is located at the center of the network, embedded in a dense, regional cluster of mostly coastal towns. Previous research measures Hansa membership using dummy variables that assign the same value to Hamburg and Cologne (both $1=$ Yes) and ignore their differences in historical embeddedness. Our network data show that Hamburg is connected to more towns than Cologne through at least one joint Hansa event (degree: $33>22$ ). Hamburg was also more deeply involved as is evident when all interactions are counted for each town (weighted degree sum: $149>41$ ). Figure 1 shows how this is reflected in differences in numbers of ties as well as in strengths of ties as marked by the width of lines. We calculate a generalized degree of 10.49 for Cologne and 27.55 for Hamburg (alpha $=0.5)$ suggesting that the Northern German town and center of the Northern Reformation was much more deeply embedded in Hansa politics despite Cologne's large size and economic importance. This relationship is obscured if we use a binary Hansa membership variable as a proxy as in previous studies of the Protestant Reformation.

The core members of the Hansa appear to have had a substantial structural potential for cohesion and solidarity. The size of the total network of diet-attending Hanseatic cities is small, reinforcing the small group character among the "core" members involved in Hansa politics and governance. This structure may be hidden by binary measures that suggest a larger structure by including nonattending towns in the Hansa group.

Although we identified a wider group of 73 Hansa towns in the overall data set, we limit the network analyses to 34 towns active in Hansa events in the 25-year period before 1517 and linked through 390 ties of joint participation. To characterize the features of the urban network, we start with two features that have been considered as key in urban studies: density and centralization. Neal (2013: 119) states that network density and centralization characterize functional polycentricity in urban networks. The cumulative Hansa town network depicted in figure 1 shows a relatively high density $($ density $=0.695)$ and moderate levels of hierarchy $($ centralization $=0.32)$ in the simplified (binary) network. This network structure suggests a moderate to 
high functional polycentricity score of 0.47 . Modern urban networks that show the characteristic horizontal linkages of polycentric networks are Southern California and the Randstad region in the Netherlands (ibid.: 120). A recent empirical study of the period from 1986 to 2006 found that research collaboration among European cities have a network density of 6 percent, a diameter of 4 , and an average path length of 2 (Comin 2013: 181).

The distance of the Hansa network is relatively short with a diameter of 2 and an average path length similar to those reported by Centola (2015) susceptible for complex diffusion (distance $=1.301$ ). Both measures suggest that information traveled relatively quickly in the Hansa town network. Finally, clustering is another factor considered by Centola and may be important particularly for complex diffusion. The Hansa network shows high transitivity (global clustering coefficient $=0.83$ ). Using Opsahl's (2013) clustering coefficient for two-mode networks, we get a slightly lower coefficient of 0.73 . These coefficients describe the density of the local neighborhoods, which is even higher than the density of the total network. Generally, Hansa towns seem to be highly "embedded in dense local neighborhoods" (Hanneman and Riddle 2011: 346).

These descriptive findings confirm our expectation that the structure of the Hansa network fits the criteria for complex diffusion. The structure enabled the spread of information through multiple channels in the early years of the Reformation; it also offered multiple opportunities for support and reinforcement, particularly at the center of the network. By contrast, cities on the edge of the network such as Cologne (Köln), Deventer, and Soest had less such support, an additional factor that may account for why towns on the Westphalian perimeter of the Hansa were more prone to remain Catholic (Scribner 1976).

\section{Multivariate Results}

Individual Hansa towns differed dramatically in their involvement in Hansa politics and attendance of Hansa events. This different activity creates various network positions in our cumulative network. Engagement leaves traces in the form of connections between towns indicating a shared history and potential interpersonal communication between Hansa delegates. The different numbers of connections of towns in figure 1 illustrate this and reveal a central "core" of towns highly interconnected by many events, particularly Bremen (HB), Hamburg (HH), Lübeck (HL), Lüneburg (LG), Rostock (HRO), Stralsund (HST), and Wismar (HWI). All other towns seem to be peripheral but differ in levels of Hansa involvement and numbers of connections to other towns.

To assess our hypotheses, we estimate a series of binary probit regression models on reform, a categorical variable (Long 1997). All models use robust standard errors clustering by territory, which takes into consideration that reform may have spread more quickly within territories due to spatial proximity. ${ }^{9}$ In our analysis of the

9. Other than free and imperial cities that are considered to be their own territory, our coding of territories follows Rubin (2014). 


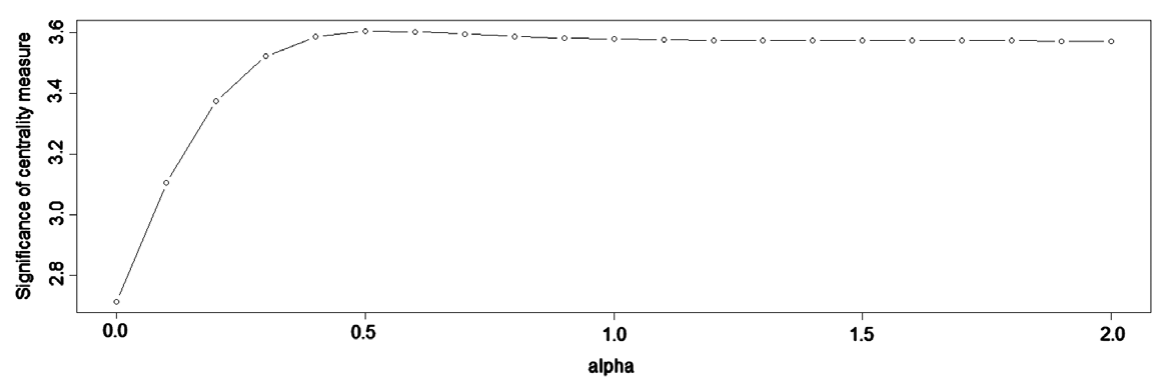

FIGURE 2. Significance levels of generalized degree centrality across alpha parameters.

diffusion of the Reformation, we consider the social and political embeddedness of Hansa towns based on the history of attendance at Hansa events. The network structure of each individual town has important implications for the Reformation process due to potentially varying information flows and social reinforcement.

To determine if the network structure variables can account for the effect of Hansa membership, we compare the Hansa membership effect between models with and without the network structure variables and test whether the Hansa membership coefficient is significantly reduced using Seemingly Unrelated Estimation (SUEST). Suest handles the possibility of the cross-equation correlation of errors by simultaneously estimating a Huber-white sandwich covariance matrix (see Clogg et al. 1995).

We analyze how social embeddedness affects the adoption of the Protestant Reformation among towns by focusing on their structural position in the Hansa network of towns using generalized centrality measures. Opsahl et al. (2010: 50) note the difficulty of determining the exact tuning parameter and suggest that finding optimal alpha parameters may be a potential area for research. We calculate the maxima for each measure over the range of alpha values in probit models predicting reform. We use the alpha parameter with the highest levels of significance calculated in the sample of Hansa towns only. Figures 2 through 4 show the significance levels of all three generalized centrality measures across alpha. The optimal tuning parameters are 0.5 (degree), 2.0 (closeness), and both 0.1 and 1.1 (betweenness). Thus, we find support for hypothesis 2 about the importance of tie strength and numbers of ties. Evidence for the hypothesis 3 is mixed.

Tables 3 and 4 show the results from probit regressions of adoption of Protestant Reformation by 1530 on covariates. Results are based on the sample of 753 towns in Europe (table 3) as compiled by Rubin (2014) as well as results for a reduced sample of only Hansa towns (table 4). Our analyses show that all network variables are statistically significant and show in the direction expected by our hypotheses. These results hold across all alpha values as depicted in figures 2 through 4 . In the tables, we show results for the maxima we found only. In table 3, model 1, Hansa membership significantly increases the likelihood of reforming by 1530 . In model 2, when Generalized 
TABLE 3. Probit regression predicting Protestant Reform by 1530. Unstandardized coefficients and average marginal effects displayed (robust clustered Standard Error by territory)

\begin{tabular}{|c|c|c|c|c|c|c|c|c|c|c|}
\hline & \multicolumn{2}{|c|}{ Model 1} & \multicolumn{2}{|c|}{ Model 2} & \multicolumn{2}{|c|}{ Model 3} & \multicolumn{2}{|c|}{ Model 4} & \multicolumn{2}{|c|}{ Model 5} \\
\hline & $b$ & $A M E$ & $b$ & $A M E$ & $b$ & $A M E$ & $b$ & $A M E$ & $b$ & $A M E$ \\
\hline $\operatorname{Ln}($ Pop $)$ & $\begin{array}{c}-.42^{* *} \\
(.16)\end{array}$ & -.04 & $\begin{array}{c}-.44^{* *} \\
(.13)\end{array}$ & -.05 & $\begin{array}{c}-.43^{* *} \\
(.16)\end{array}$ & -.04 & $\begin{array}{c}-.43^{* *} \\
(.16)\end{array}$ & -.04 & $\begin{array}{c}-.43^{* *} \\
(.16)\end{array}$ & -.04 \\
\hline Press & $\begin{array}{c}.15 \\
(.24)\end{array}$ & .02 & $\begin{array}{c}.13 \\
(.25)\end{array}$ & .01 & $\begin{array}{l}.10 \\
(.25)\end{array}$ & .01 & $\begin{array}{c}.11 \\
(.25)\end{array}$ & .01 & $\begin{array}{l}.11 \\
(.25)\end{array}$ & .01 \\
\hline Market Potential & $\begin{array}{c}-.25^{* * *} \\
(.06)\end{array}$ & -.03 & $\begin{array}{c}-.25^{* * * *} \\
(.06)\end{array}$ & -.03 & $\begin{array}{c}-.25^{* * *} \\
(.06)\end{array}$ & -.03 & $\begin{array}{c}-.25^{* * *} \\
(.06)\end{array}$ & -.03 & $\begin{array}{c}-.25^{* * *} \\
(.06)\end{array}$ & -.03 \\
\hline Ln(DistWitt) & $\begin{array}{c}-.94^{* * * *} \\
(.18)\end{array}$ & -.10 & $\begin{array}{c}-.94^{* * *} \\
(.18)\end{array}$ & -.10 & $\begin{array}{c}-.93^{* * *} \\
(.18)\end{array}$ & -.10 & $\begin{array}{c}-.94^{* * *} \\
(.18)\end{array}$ & -.10 & $\begin{array}{c}-.93^{* * *} \\
(.18)\end{array}$ & -.10 \\
\hline Ln(DistZurich) & $\begin{array}{c}-1.10^{* * * *} \\
(.28)\end{array}$ & -.12 & $\begin{array}{c}-1.12^{* * *} \\
(.28)\end{array}$ & -.12 & $\begin{array}{c}-1.12^{* * *} \\
(.28)\end{array}$ & -.12 & $\begin{array}{l}1.13^{* * * *} \\
(.28)\end{array}$ & -.12 & $\begin{array}{c}-1.10^{* * *} \\
(.28)\end{array}$ & -.11 \\
\hline Independent City & $\begin{array}{l}.48 \\
(.37)\end{array}$ & .05 & $\begin{array}{c}.37 \\
(.39)\end{array}$ & .04 & $\begin{array}{l}.32 \\
(.41)\end{array}$ & .03 & $\begin{array}{c}.38 \\
(.39)\end{array}$ & .04 & $\begin{array}{c}.39 \\
(.39)\end{array}$ & .04 \\
\hline Lay Magnate & $\begin{array}{c}-.92^{* *} \\
(.33)\end{array}$ & -.10 & $\begin{array}{c}-.96^{* *} \\
(.34)\end{array}$ & -.10 & $\begin{array}{c}-.98^{* *} \\
(.34)\end{array}$ & -.10 & $\begin{array}{c}-.95^{* *} \\
(.33)\end{array}$ & -.10 & $\begin{array}{c}-.97^{* * *} \\
(.34)\end{array}$ & -.10 \\
\hline Bishop & $\begin{array}{r}-.51^{*} \\
(.25)\end{array}$ & -.05 & $\begin{array}{r}-.52^{*} \\
(.25)\end{array}$ & -.05 & $\begin{array}{r}-.56^{*} \\
(.26)\end{array}$ & -.06 & $\begin{array}{r}-.57^{*} \\
(.26)\end{array}$ & -.06 & $\begin{array}{r}-.51^{*} \\
(.25)\end{array}$ & -.05 \\
\hline Water & $\begin{array}{l}.13 \\
(.16)\end{array}$ & .01 & $\begin{array}{l}.09 \\
(.16)\end{array}$ & .01 & $\begin{array}{l}.11 \\
(.16)\end{array}$ & .01 & $\begin{array}{l}.13 \\
(.16)\end{array}$ & -.01 & $\begin{array}{l}.11 \\
(.16)\end{array}$ & .01 \\
\hline University & $\begin{array}{r}-.29 \\
(.39)\end{array}$ & -.03 & $\begin{array}{r}-.36 \\
(.41)\end{array}$ & -.04 & $\begin{array}{r}-.22 \\
(.40)\end{array}$ & -.02 & $\begin{array}{r}-.28 \\
(.40)\end{array}$ & -.03 & $\begin{array}{r}-.38 \\
(.40)\end{array}$ & -.04 \\
\hline Hansa Membership & $\begin{array}{l}.75^{* *} \\
(.28)\end{array}$ & .08 & $\begin{array}{l}.52 \\
(.32)\end{array}$ & .05 & $\begin{array}{l}.61^{*} \\
(.29)\end{array}$ & .06 & $\begin{array}{l}.65^{*} \\
(.29)\end{array}$ & .07 & $\begin{array}{l}.63^{*} \\
(.29)\end{array}$ & .07 \\
\hline Degree Generalized $(\alpha$ 0.5) & & & $\begin{array}{l}.05^{*} \\
(.02)\end{array}$ & .01 & & & & & & \\
\hline Betweenness Generalized ( $\alpha 0.1)$ & & & & & $\begin{array}{l}.07^{*} \\
(.03)\end{array}$ & .01 & & & & \\
\hline Betweenness Generalized ( $\alpha$ 1.1) & & & & & & & $\begin{array}{c}.02^{*} \\
-0.01\end{array}$ & 0.002 & & \\
\hline Closeness Generalized ( $\alpha$ 2.0) & & & & & & & & & $\begin{array}{c}0.009^{*} \\
-0.005 \\
\end{array}$ & .001 \\
\hline Constant & $\begin{array}{l}16.19^{* * * *} \\
(3.12)\end{array}$ & & $\begin{array}{l}16.41^{* * * *} \\
(3.13)\end{array}$ & & $\begin{array}{l}16.34^{* * *} \\
(3.14)\end{array}$ & & $\begin{array}{l}16.46^{* * *} \\
(3.15)\end{array}$ & & $\begin{array}{l}16.15^{* * *} \\
(3.12)\end{array}$ & \\
\hline${ }^{* * *} p<.001 ;{ }^{* *} p<.01{ }^{*} p<.05 ;+p<.10$ & 753 & & 753 & & 753 & & 753 & & 753 & \\
\hline
\end{tabular}


TABLE 4. Probit regression predicting Protestant Reform by 1530 in Hansa towns. Unstandardized coefficients and average marginal effects displayed (robust clustered SE by territory)

\begin{tabular}{|c|c|c|c|c|c|c|c|c|c|c|}
\hline & \multicolumn{2}{|c|}{ Model 6} & \multicolumn{2}{|c|}{ Model 7} & \multicolumn{2}{|c|}{ Model 8} & \multicolumn{2}{|c|}{ Model 9} & \multicolumn{2}{|c|}{ Model 10} \\
\hline & $b$ & $A M E$ & $b$ & $A M E$ & $b$ & $A M E$ & $b$ & $A M E$ & $b$ & $A M E$ \\
\hline Ln(Pop) & $\begin{array}{r}-1.01^{*} \\
(.51)\end{array}$ & -.22 & $\begin{array}{r}-1.30^{*} \\
(.58)\end{array}$ & -.24 & $\begin{array}{r}-1.09^{*} \\
(.55)\end{array}$ & -.20 & $\begin{array}{r}-1.22^{*} \\
(.57)\end{array}$ & -.23 & $\begin{array}{r}-1.18^{*} \\
(.56)\end{array}$ & -.21 \\
\hline Press & $\begin{array}{l}.95 \\
(.62)\end{array}$ & -.20 & $\begin{array}{c}.96 \\
(.67)\end{array}$ & .17 & $\begin{array}{c}.48 \\
(.69)\end{array}$ & .09 & $\begin{array}{l}.51 \\
(.63)\end{array}$ & .10 & $\begin{array}{l}.85 \\
(.66)\end{array}$ & .15 \\
\hline Market Potential & $\begin{array}{c}-1.00^{* * * *} \\
(.28)\end{array}$ & -.22 & $\begin{array}{c}-1.20^{* * * *} \\
(.34)\end{array}$ & -.22 & $\begin{array}{c}-1.21^{* * *} \\
(.34)\end{array}$ & -.22 & $\begin{array}{c}-1.25^{* * *} \\
(.35)\end{array}$ & -.24 & $\begin{array}{c}-1.31^{* * *} \\
(.37)\end{array}$ & -.24 \\
\hline Ln(DistWitt) & $\begin{array}{c}-.04 \\
(.38)\end{array}$ & -.009 & $\begin{array}{c}.08 \\
(.38)\end{array}$ & .01 & $\begin{array}{c}-.02 \\
(.36)\end{array}$ & -.004 & $\begin{array}{r}-.16 \\
(.38)\end{array}$ & -.03 & $\begin{array}{l}.29 \\
(.41)\end{array}$ & .05 \\
\hline Ln(DistZurich) & $\begin{array}{c}-12.07^{* *} \\
(3.91)\end{array}$ & -2.61 & $\begin{array}{c}-14.59^{* *} \\
(4.56)\end{array}$ & -2.65 & $\begin{array}{c}-14.72^{* *} \\
(4.59)\end{array}$ & -2.64 & $\begin{array}{c}-14.93^{* *} \\
(4.63)\end{array}$ & -2.84 & $\begin{array}{c}-16.43^{* *} \\
(5.04)\end{array}$ & -2.99 \\
\hline Independent City & $\begin{array}{c}.09 \\
(.68)\end{array}$ & .02 & $\begin{array}{r}-.68 \\
(.75)\end{array}$ & -.12 & $\begin{array}{c}-1.30+ \\
(.76)\end{array}$ & -.23 & $\begin{array}{r}-1.04 \\
(.73)\end{array}$ & -.20 & $\begin{array}{r}-.51 \\
(.76)\end{array}$ & -.09 \\
\hline Lay Magnate & $\begin{array}{c}-2.87^{* * *} \\
(.82)\end{array}$ & -.62 & $\begin{array}{c}-3.43^{* *} \\
(1.00)\end{array}$ & -.62 & $\begin{array}{c}-3.45^{* * *} \\
(.92)\end{array}$ & -.62 & $\begin{array}{c}-3.54^{* * *} \\
(.99)\end{array}$ & -.67 & $\begin{array}{c}-3.49^{* *} \\
(1.02)\end{array}$ & -.64 \\
\hline Bishop & $\begin{array}{r}-1.69^{*} \\
(.68)\end{array}$ & -.37 & $\begin{array}{c}-1.91^{* *} \\
(.70)\end{array}$ & -.35 & $\begin{array}{c}-2.17^{* *} \\
(.68)\end{array}$ & -.39 & $\begin{array}{c}-2.26^{* *} \\
(.71)\end{array}$ & -.43 & $\begin{array}{c}-1.95^{* *} \\
(.74)\end{array}$ & -.35 \\
\hline Water & $\begin{array}{l}.63 \\
(.50)\end{array}$ & .14 & $\begin{array}{c}.34 \\
(.55)\end{array}$ & .06 & $\begin{array}{l}.27 \\
(.56)\end{array}$ & .05 & $\begin{array}{l}.36 \\
(.54)\end{array}$ & .07 & $\begin{array}{l}.40 \\
(.56)\end{array}$ & .07 \\
\hline University & $\begin{array}{r}-.43 \\
(.76)\end{array}$ & -.09 & $\begin{array}{r}-.85 \\
(.60)\end{array}$ & -.15 & $\begin{array}{l}.37 \\
(.66)\end{array}$ & .07 & $\begin{array}{r}-.23 \\
(.86)\end{array}$ & -.04 & $\begin{array}{c}-.98+ \\
(.57)\end{array}$ & -.18 \\
\hline Degree Generalized $(\alpha 0.5)$ & & & $\begin{array}{l}.09^{* *} \\
(.02)\end{array}$ & .02 & & & & & & \\
\hline Betweenness Generalized ( $\alpha 0.1)$ & & & & & $\begin{array}{l}.11^{* *} \\
(.03)\end{array}$ & .02 & & & & \\
\hline Betweenness Generalized ( $\alpha$ 1.1) & & & & & & & $\begin{array}{l}.04^{* *} \\
(.01)\end{array}$ & .008 & & \\
\hline Closeness Generalized ( $\alpha$ 2.0) & & & & & & & & & $\begin{array}{l}.02^{* * *} \\
(.005)\end{array}$ & .003 \\
\hline Constant & $\begin{array}{l}93.95^{* *} \\
(29.85)\end{array}$ & & $\begin{array}{l}112.91^{* *} \\
(34.39)\end{array}$ & & $\begin{array}{l}114.35^{* *} \\
(34.92)\end{array}$ & & $\begin{array}{l}117.30^{* *} \\
(35.82)\end{array}$ & & $\begin{array}{l}124.75^{* *} \\
(37.73)\end{array}$ & \\
\hline $\begin{array}{l}\mathrm{N} \\
{ }^{* * *} \mathrm{p}<.001 \text { ** }^{* *} \mathrm{p}<.01 ;{ }^{*} \mathrm{p}<.05 ;+\mathrm{p}<.10 .\end{array}$ & 64 & & 64 & & 64 & & 64 & & 64 & \\
\hline
\end{tabular}




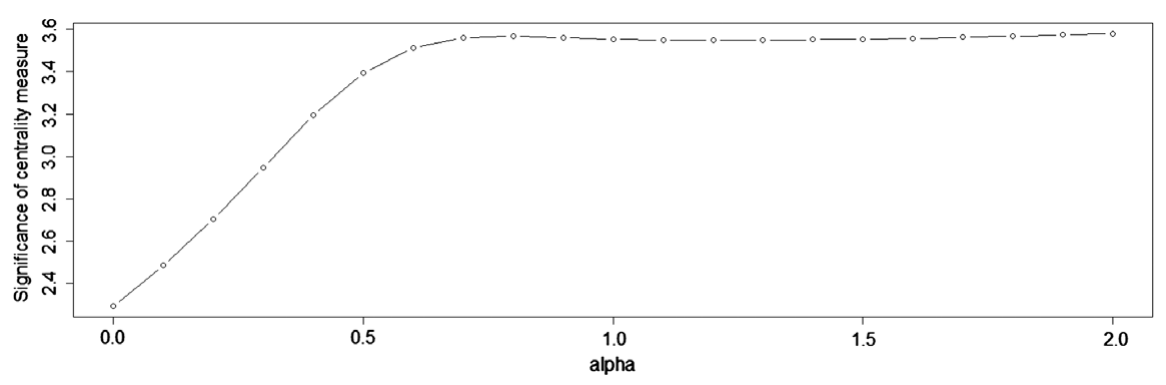

FIGURE 3. Significance levels of generalized closeness centrality across alpha parameters.

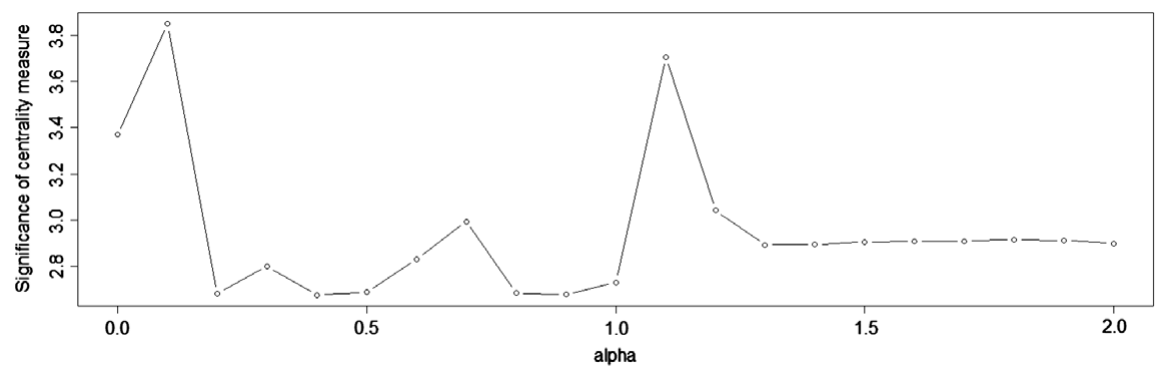

FIGURE 4. Significance levels of generalized betweenness centrality across alpha parameters.

degree centrality ( $\alpha=0.5$ ) is added, the coefficient for Hansa membership is no longer statistically significant, which indicates that generalized degree centrality completely explains the significant relationship between Hansa membership and reform. According to test results, each of the other structural measures significantly reduces the relationship between Hansa membership and reform: Betweenness Generalized ( $\alpha=$ $0.1)[\chi 2=5.11, \mathrm{p}<.05]$, generalized betweenness centrality $(\alpha=1.1)[\chi 2=3.37$, $\mathrm{p}<.10]$, and generalized closeness centrality $(\alpha=2.0)[\chi 2=4.00, \mathrm{p}<.05]$. Across models 2 through 5 , the coefficients indicate that favorable structural positions in the Hansa network of towns increase the likelihood of reform by 1530 . This is also the case in table 4, which estimates models for Hansa towns only. Thus, we find support for hypotheses 4 through 6: Having more connections to other Hansa towns (degree), being relationally closer to other Hansa towns (closeness), and occupying positions with brokerage potential (betweenness) increase the odds of adoption.

An interesting finding is that printing press is not statistically significant in our models. As we are analyzing the early stage of the Reformation, this suggests that informal social relations may have been particularly decisive during this stage of 
the diffusion process over the spread of printed materials. There is good historical evidence to suggest that preaching and debates played a substantial role in spreading the early Protestant movement (Hannemann 1975; Kim and Pfaff 2012). In later stages of the Reformation, as analyzed by Rubin (2014), formal means of communicating information and influencing political elites may have been more important as Rubin's (2014) findings suggest. ${ }^{10}$ Our statistical models confirm this interpretation because our Hansa network measures are no longer significant if we regress adoption in 1560 on our covariates (results not shown). Hence, in generating early waves of adoption, our findings suggest that social influence and social reinforcement may be more important in complex diffusion than are formal channels.

\section{Conclusion and Implications}

Previous social-scientific research on the adoption of the Reformation finds that the motives that propelled the institutional reforms in the cities varied from place to place but can be summarized, usually in some combination, as being linked to "piety, power and the purse" (Pfaff and Corcoran 2012). In the present study, we go beyond these factors to analyze how social diffusion facilitated by the social network relations between cities explains why some cities were more prone to embrace reform. The association between network ties and social diffusion in our sample of Hansa towns provides evidence for both simple and complex contagion. Our analyses show that historically embedded networks may offer the ideal structural conditions for the spread of new controversial religious and governance practices. While scholars of the Reformation have drawn on network concepts focusing on change agents (Hannemann 1975; Kim and Pfaff 2012), no previous study has used relational network data. Our operationalization of a new network data set based on medieval Hansa Diets allows us to consider the network structure of towns up to the eve of the Reformation. We analyze weighted event data from Hansa Diets from 1492 to 1516 using generalized centrality measures, and point to the complex association between tie weights (i.e., the strength of ties) and numbers of ties in network diffusion. Using optimal tuning parameters for simple adoption models, we show that a combination of strong ties and weak ties mattered for adoption.

Taken together, our results suggest that there is a general disposition favoring reform across Hansa towns. Existing social-scientific accounts would suggest that the reason behind this pattern lies in the greater wealth and commercial development of Hansa cities compared with other cities in the HRE. Our findings cast doubt on this interpretation. As a control for an economically derived demand for reform or as a proxy for the relative importance of commerce or mercantile interests in city governance,

10. The results may also be due to the fact that we do not use an instrumental variable approach for estimating the effect of the printing press on reform as we merely control for it. Rubin (2014) finds statistically significant effects for the printing press primarily in models using an instrumental variable analysis. 
the inclusion of Hanseatic membership as an indicator variable in previous studies may be misleading; mere membership tells us little about the odds of reform as more involved Hansa cities are largely responsible for this association.

Our study finds that Protestantism took off in the northern regions of Germany, in part, because structures of social relations and shared cultural identity enhanced solidarity among Hansards. This, in turn, contributed to the rapid diffusion of Protestantism across cities. Of course, one reason that Hanseatic cities may have influenced each other in adopting Protestantism is that it was in their collective interest to have a single religion. Once towns began to adopt the Reformation in the early 1520s, there would have been pressure on other Hansards to do the same. Religious differences had the potential to threaten the social glue-such as the cross-cutting ties of friendship and intermarriage that linked cities urban elites and Hansa delegates-upon which economic union was predicated. The religious sphere was highly intertwined with civic affairs, trade, and commerce, particularly as burghers were tightly linked through corporate groups such as guilds and religious confraternities (Richardson 2005; Selzer 2010).

Organizational structures like the Hansa, which cut across subgroups and across localities, are particularly apt to provide opportunities for complex diffusion. The Hanseatic cities were densely connected through multiple relations of kinship, marriage, trade, and politics. This promoted not only cultural similarity but also fostered institutions and organizational ties that made the flow of information and influence more efficient than in more socially isolated regions of the HRE. The extensive social ties among Hansards across cities and their joint involvement in governance enhanced the susceptibility of the Hansa cities to the diffusion of Protestantism.

Hanseatic structures may have been efficient because they overcame parochialism but, ironically, did not overcome relational segregation by making membership exclusive (Centola 2015: 1315). The reason is that without moderate consolidation there are no meaningful groups and without them the exercise of social influence is less salient. Exclusive organizations like the Hansa inadvertently promote complex diffusion within their network by making group membership highly salient. This reinforces the social influence that other's behavior in the network can have on potential adopters. At the same time, the overlapping ties and the bridges across social locations create a structure especially favorable to information brokerage and extralocal influence (ibid.: 1322; see also Burt 2005).

The Hansa created cross-cutting connections between the otherwise discrete medieval social circles that ordinarily segregated groups and regions. Because transportation was expensive and traveling was dangerous, late medieval urban economies were largely local in scale, chiefly dependent on adjacent agrarian areas for which they served as a market for manufactured goods (Nicholas 2003; Rozman 1978; Russel 1972). More extensive, cross-cutting urban networks developed through long-distance trade relationships of the kind that the Hansa actively promoted. The Hansa became a supraregional network of local elites who interacted both at home and abroad. In addition to trade relations, ties between Hansa cities were generated through participation in the governing institutions of the organization. 
Our study finds strong support for our relational explanation of the Hansa cities and the coming of the Reformation. While previous research on networks and diffusion pointed to the importance of network topologies, these studies have begun to include aspects about the origins of networks (Centola 2015). Our study suggests that social, economic, and political embeddedness of social relations influenced Protestant diffusion. Although we find clear evidence of spatial diffusion from the ideological centers of the nascent Protestant movement in the negative relationship between reform in a city and distance from Wittenberg and Zürich, our findings also suggest that there was diffusion through network relations (and these relationships remain significant in our models that include our measures of spatial diffusion). Future work in the comparative and historical social sciences should consider relational processes alongside political economy if we wish to arrive at reliable and general explanations of major institutional changes.

\section{Mini Glossary}

Centralization: Measure used to capture hierarchy in a network considering the distribution of the numbers of ties. If all nodes have the same number of ties, centralization is 0 , and if all ties are linked to the central node, centralization is 1 resembling a network star (Wasserman and Faust 1994: 177).

Characteristic path length: Network measure that reports how many ties must be passed through to navigate between any two nodes in a network, on average (Centola 2015: 1314).

Clustering coefficient: Network measure of the number of closed triads divided by the number of two paths. A closed triad is a structure in which three nodes are all connected to each other. Two paths have only two ties between three nodes (Centola 2015: 1311).

Degree centrality: The number of ties a single node has to other nodes. For instance, Hansa towns with a network degree of 20 established the same amount of (unweighted) ties to other Hansa towns in at least one shared event in the period of observation.

Density: Network measure of connectivity or cohesion based on the number of observed ties divided by the number of possible ties.

Diameter: The largest distance between any two pairs of nodes in a network.

Functionally polycentric: "A network is functionally polycentric when it contains a large number of edges (it is dense), and when these edges are evenly spread among the nodes (it is not centralized)." The polycentricity score can be calculated as follows: Density * (1-Centralization) (Neal 2013: 119).

Graph: Visualization of a network including nodes and lines representing actors and ties.

Isolates: Nodes that do not have any ties are unconnected, which means not part of the network.

Networks: Structures that include nodes (actors, e.g., organizations) and ties (relationships, e.g., collaborations).

Total network: Networks can be analyzed at the nodal level, subgroup level, and aggregate level. The total network is the all-encompassing set of nodes and ties that can be described by global measures such as density.

\section{References}

Asche, M. (1999) "Der Ostseeraum als Universitäts- und Bildungslandschaft im Spätmittelalter und in der Frühen Neuzeit.” Blätter für deutsche Landesgeschichte 135: 1-20. 
Bairoch, P. (1988) Cities and Economic Development. Chicago: University of Chicago Press.

Becker, S., and L. Woessmann (2008) "Luther and the girls: Religious denomination and the female education gap in nineteenth-century Prussia." The Scandinavian Journal of Economics 110 (4): 777805 .

(2009) "Was Weber wrong? A human capital theory of Protestant economic history." The Quarterly Journal of Economics 124 (2): 531-96.

Becker, S., S. Pfaff, and J. Rubin (2016) "Causes and consequences of the Protestant Reformation." Explorations in Economic History 62: 1-25.

Blickle, P. (1992) Communal Reformation. London: Humanities.

Blockmans, W. (2010) Inclusiveness and exclusion: Trust networks at the origins of European cities. Theory and Society 39 (3-4): 315-26.

Bonacich, P. (1987) "Power and centrality: A family of measures." American Journal of Sociology 92 (5): $1170-82$.

Borgatti, S. (2005) “Centrality and network flow.” Social Networks 27 (1): 55-71.

Brady, T. (1998) Communities, Politics, and Reformation in Early Modern Europe. Leiden, The Netherlands: Brill.

(1999) "The Reformation of the common man, 1521-1524," in C. Dixon (ed.) The German Reformation. London: Blackwell: 91-132.

Breiger, R. (1974) “The duality of persons and groups.” Social Forces 53 (2): 181-90.

Burt, R. (1987) "Social contagion and innovation: Cohesion vs. structural equivalence.” American Journal of Sociology 92 (6): 1287-1335.

(1992) Structural Holes: The Social Structure of Competition. Cambridge, MA: Harvard University Press.

(2005) Brokerage and Closure. Chicago: University of Chicago Press.

Cantoni, D. (2012) "Adopting a new religion: The case of Protestantism in 16th century Germany." The Economic Journal 122 (560): 502-31.

Castells, M. (1996) The Rise of the Network Society. Malden, MA: Blackwell.

Centola, D. (2015) "The social origins of networks and diffusion." American Journal of Sociology 120 (5): 1295-1338.

Centola, D., and M. Macy (2007) "Complex contagions and the weakness of long ties." American Journal of Sociology 113 (3): 702-34.

Cheney, D. M. (2017) The Hierarchy of the Catholic Church. Accessed on January 17, 2018, http:// catholic-hierarchy.org.

Clair, C. (1976) A History of European Printing New York: Academic Press.

Clogg, Clifford C., E. Petkova, and A. Haritou (1995) "Statistical methods for comparing regression coefficients between models.” American Journal of Sociology 100 (5): 1261-93.

Coleman, J., E. Katz, and H. Menzel (1957) “The diffusion of an innovation among physicians." Sociometry 20 (4): 253-70.

Comin, M. (2013) "The capture and diffusion of knowledge spillovers: The influence of position of cities in a network," in C. Rozenblat and G. Melançon (eds.) Methods for Multilevel Analysis and Visualisation of Geographical Networks. Dordrecht, The Netherlands: Springer: 177-88.

Curuk, M., and S. Smulders (2016) "Malthus meets Luther: The economics behind the German Reformation.” CESifo Working Papers No. 6010.

Davis, G., and H. Greve (1997) “Corporate elite networks and governance changes in the 1980s.” American Journal of Sociology 103 (1): 1-37.

Dittmar, J., and S. Seabold (2014) "New media, markets, and institutional change: Evidence from the Protestant Reformation." Unpublished manuscript.

Dixon, C. (2000) "The princely Reformation in Germany," in A. Pettegree (ed.) The Reformation World. New York: Routledge.

Dollinger, P. (1970) The German Hansa. London: Macmillan. (1989) Die Hanse. Stuttgart, Germany: Kröner. 
Ekelund, R., R. Hebert, and R. Tollison (2006) The Marketplace of Christianity. Cambridge, MA: MIT Press.

Ekelund, R., R. Hebert, R. Tollison, G. Anderson, and A. Anderson (1996) Sacred Trust: The Medieval Church as an Economic Firm. New York: Oxford University Press.

Estrada, E. (2012) The Structure of Complex Networks: Theory and Applications. New York: Oxford University Press.

Febvre, L., Martin, H.-J. (1958) The Coming of the Book: The Impact of Printing, 1450-1800. London: Verso.

Freeman, L. (1978) "Centrality in social networks: Conceptual clarification.” Social Networks 1 (3): 215-39.

Granovetter, M. (1973) “The strength of weak ties.” American Journal of Sociology 78 (6): 1360-80.

(1985) "Economic action and social structure: The problem of embeddedness." American Journal of Sociology 91 (3): 481-510.

Grund, T. (2016) "The relational value of network experience in teams: Evidence from the English Premier League." American Behavioral Scientist 60 (10): 1260-80.

Hammel-Kiesow, R. (2008) Die Hanse. Munich: C. H. Beck.

Hannemann, M. (1975) "The diffusion of the Reformation in Southwestern Germany, 1518-1534." Research Paper No. 167. University of Chicago, Department of Geography.

Hanneman, R., and M. Riddle (2011) "Concepts and measures for basic network analysis," in J. Scott and P. Carrington (eds.) The SAGE Handbook of Social Network Analysis. Thousand Oaks, CA: Sage.

Jacob, M. (2010) "Long-term persistence: The Free and Imperial City Experience." https://doi.org/10. 2139/ssrn.1616973 (accessed January 17, 2018).

Jahnke, C. (2014) Die Hanse. Stuttgart, Germany: Reclam.

Kim, H., and S. Pfaff (2012) "Structure and dynamics of religious insurgency: Students and the spread of the Reformation.” American Sociological Review 77 (2): 188-215.

Kohler, A. (1990) Das Reich im Kampf um die Hegemonie in Europa, 1521-1648. Munich: Oldenbourg.

Korell, G. (1980) Jürgen Wullenwever. Weimar, Germany: Böhlau.

Long, J. S. (1997) Regression Models for Categorical and Limited Dependent Variables. Los Angeles: Sage.

Moeller, B. (1972) Imperial Cities and the Reformation. Philadelphia: Fortress.

Mörke, O. (2005) Die Reformation. Munich: Oldenbourg.

Neal, Z. (2013) The Connected City: How Networks Are Shaping the Modern Metropolis. New York: Routledge.

Neuhaus, H. (1997) Das Reich in der Frühen Neuzeit. Munich: Oldenbourg.

Newman, M. (2001) "Scientific collaboration networks: II. Shortest paths, weighted networks, and centrality." Physical Review E (64) 016132: 1-7.

Nexon, D. (2009) The Struggle for Power in Early Modern Europe. Princeton, NJ: Princeton University Press.

Nicholas, D. (2003) Urban Europe, 1100-1700. London: Palgrave Macmillan.

Opsahl, T. (2013) "Triadic closure in two-mode networks: Redefining the global and local clustering coefficients." Social Networks 35 (2): 159-67.

Opsahl, T., F. Agneessens, and J. Skvoretz (2010) "Node centrality in weighted networks: Generalizing degree and shortest paths." Social Networks 32 (3): 245-51.

Ozment, S. (1975) The Reformation in the Cities. New Haven, CT: Yale University Press.

Pagel, K. (1983) Die Hanse. Braunschweig, Germany: Westermann.

Peters, E. (1939) "Das große Sterben des Jahres 1350 in Lübeck und seine Auswirkungen auf die wirtschaftliche und soziale Strukture der Stadt." Zeitschrift des Vereins für Lübeckische Geschichte und Altertumskunde 30 (1): 15-148.

Pfaff, S., and K. Corcoran (2012) "Piety, power, and the purse: Religious economies theory and urban reform in the Holy Roman Empire." Journal for the Scientific Study of Religion 51 (4): 757-76.

Pichierri, A. (2000) Die Hanse. Staat der Städte. Ein ökonomisches und politisches Modell der Städtevernetzung. Opladen, Germany: Leske + Budrich. 
Poeck, D. (2010) Die Herren der Hanse. Delegierte und Netzwerke. Frankfurt am Main: Peter Lang.

Postel, R. (2006) "Motive Staedtischer Reformation in Norddeutschland," in L. Jockheck (ed.) Beiträge zur hamburgischen Geschichte der frühen Neuzeit: 11-33.

(2009) "Enye gans nye ferlicke sect—die Hansestädte und die Reformation," in A. Gra $\beta$ mann

(ed.) Der Kaufmann und der liebe Gott. Zu Kommerz und Kirche in Mittelalter und Früher Neuzeit. Trier, Germany: Porta Alba: 131-45.

Puga, D., and D. Trefler (2012) "International trade and institutional change: Medieval Venice's response to globalization.” CEPR Discussion Paper No. 9076.

Richardson, G. (2005) "Craft guilds and Christianity in late-medieval England: A rational-choice analysis." Rationality and Society 17 (2): 139-90.

Robins, G. (2015) Doing Social Network Research: Network-Based Research Design for Social Scientists. Los Angeles: Sage.

Rozenblat, C., and G. Melançon eds. (2013) Methods for Multilevel Analysis and Visualisation of Geographical Networks. Dordrecht, The Netherlands: Springer.

Rozman, G. (1978) "Urban networks and historical stages." Journal of Interdisciplinary History 9 (1): 65-91.

Rubin, J. (2014) "Printing and Protestants: An empirical test of the role of printing in the Reformation." The Review of Economics and Statistics 96 (2): 270-86.

Russell, J. (1972) Medieval Regions and Their Cities. Bloomington: Indiana University.

Sassen, S. (1991) The Global City: New York, London, Tokyo. Princeton, NJ: Princeton University Press. Schilling, H. (1983) "The Reformation in the Hanseatic cities." Sixteenth Century Journal 14 (4): 443-56. (1988) Aufbruch und Krise: Deutschland, 1517-1648. Berlin: Siedler.

Schubert, E. (1996) Fürstliche Herrschaft und Territorium im späten Mittelalter. Munich: Oldenbourg.

Scribner, R. (1976) "Why was there no Reformation in Cologne." Historical Research 49 (120): $217-41$. 237-56 (1984) "Oral culture and the diffusion of Reformation ideas." History of European Ideas 5 (3):

(1986) The German Reformation. New York: St. Martin's Press.

Seier, M. (2012) "Die Hanse auf dem Weg zum Stādtebund: Hansische Reorganisationsbestrebungen an der Wende vom 15. zum 16. Jahrhundert.” Hansische Geschichtsblätter 130: 93-125.

Selzer, S. (2010) Die mittelalterliche Hanse. Darmstadt, Germany: WBG.

Simmel, G. (1992 [1908]) Soziologie. Untersuchungen über die Formen der Vergesellschaftung. Frankfurt am Main: Suhrkamp.

Sombart, W. (1915) Händler und Helden. Munich, Germany: Duncker and Humblot.

Tawney, R. (1954 [1926]) Religion and the Rise of Capitalism. New York: Harcourt, Brace and Jovanovic.

Te Brake, W. (1998) Shaping History: Ordinary People in European Politics, 1500-1700. Berkeley: University of California Press.

Tracy, J. (ed.). (1986) Luther and the modern state in Germany. Kirksville, MO: Sixteenth Century Journal Publishers.

Tulchin, A. (2010) That men would praise the lord: The triumph of Protestantism in Nimes, 1530-1570. New York: Oxford University Press.

Uzzi, B. (1997) "Social structure and competition in interfirm networks: The paradox of embeddedness." Administrative Science Quarterly 42 (1): 35-67.

Valente, T., S. Dyal, K. Chu, H. Wipfli, and K. Fujimoto (2015) "Diffusion of innovations theory applied to global tobacco control treaty ratification." Social Science and Medicine 145: 89-97.

Veltmann, C. (2005) "Die Hanse, Westeuropa und die Ausbreitung der Reformation." Hansische Geschichtsblätter 123: 61-83.

(2009) "Die Reformation in den Hansestädten des südlichen und östlichen Ostseeraums," in

A. Gra $\beta$ mann (ed.) Der Kaufmann und der liebe Gott. Zu Kommerz und Kirche im Mittelalter und Früher Neuzeit. Hansische Studien. Band XVIII. Trier, Germany: Porta Alba: 147-62.

Wasserman, S., and K. Faust (1994) Social Network Analysis: Methods and Applications. New York: Cambridge University Press.

Weber, M. (1978 [1904-5]) Die protestantisch Ethik und der Geist des Kapitalismus. Berlin: Contumax. 
Transaction.

Wubs-Mrozewicz, J. (2012) "The Hanse in medieval and early modern Europe: An introduction," in J. Wubs-Mrozewicz, and S. Jenks (eds.) The Hanse in Medieval and Early Modern Europe. Leiden, The Netherlands: Brill: 1-35.

Zukin, S., and DiMaggio, P. (1990) "Introduction," in S. Zukin, and P. DiMaggio (eds.) Structures of Capital: The Social Organization of the Economy. New York: Cambridge University Press: 1-36. 